\title{
LOW-INCOME HOUSING SYSTEM SCHEME AND RENTAL HOUSING TYPE IN CASE OF LA PAZ CITY, BOLIVIA
}

\author{
ボリビア・ラパス市における低所得者住宅の体系と.賃貸住宅に関する研究
}

\author{
Odicea ANGELO* and Atsushi DEGUCHI** \\ オディシア アンジェロ, 出口敦
}

In order to understand the shelter strategies of the low-income people in La Paz City, this paper aims to illustrate the low-income housing system scheme, which is a hierarchical diagram where different low-income housing types can be identified, and enables to know all means that low-income people use in order to obtain housing. Deriving from analysis, it finds out that the rental type, apart from ownership, is an important housing option for the low-income people who can not usually afford to become owner-occupier due to their disadvantaged economic situation; however we find out that rented accommodation is in decline since there is not investment for improvement, neither from owners nor tenants. The research method is on the basis of an extensive study concerning the housing issue where a carefully analysis, identification and classification of the existing housing types have been developed in order to construct the low-income housing system scheme.

With the development of this scheme, we aim to clarify for planners and policy makers the achievement of more effective solutions in order to improve the living conditions of a significant portion of Bolivia's urban population.

Keywords : Low-income housing, Housing policy, Urban poverty, Developing country, Bolivia 低所得者住宅, 住宅政策, 貧困, 発展途上国, ボリビア

\section{INTRODUCTION}

For the last decades, Bolivian economy as well as most Latin American countries', has been not very effective in providing production of basic housing and financing services for the low income people. Most of the formal systems create either sub-standard or expensive solutions, thus many lowincome families are forced to live in houses, which have not basic sanitation services, and face overcrowding or inadequate protection from the unhealthy surrounding environment. In general, the activities of private sectors are addressed to higher income groups, thus housing policy has been not able to make up for the deficiencies in the private provision of housing services (Rojas, 1995).

For many years, most of the national housing programs have been just a kind of palliative for the low-income people, defined as the quantity of income received during a period of time in exchange for labor which is either at the level of the basic salary established by the Bolivian State ( 450 Bs per month) or below it, in which not many are the beneficiaries of those programs. Thus, the social sector affected by the housing problem does not have the real economic capacity to afford a house and the national financial system does not have the conditions to subsidize public housing (Van Lindert, 1991).

In 1970s, with the main aim "decent shelter for everybody", the Division of Structural Engineering and the Division of Community and Regional Development of the Asian Institute of Technology organized an international conference on low-income housing . "Tree structure", as this low-income housing scheme is named, was presented by Shlomo Angel \& et.al. (Shlomo, 1978 ) in which a hierarchical order has been constructed amongst different housing sub-systems, which are sub-divided themselves into another categories and these categories are divided into sub-categories (See Fig. 1). This scheme enables to know all means that low-income people use in order to obtain shelter.

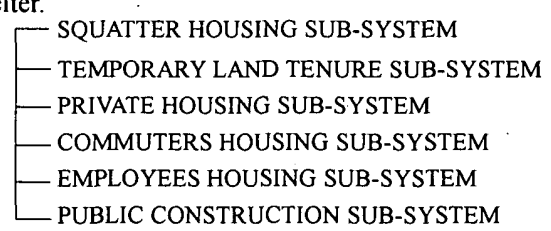

Fig.1: Main Structure of Low-income Housing System Scheme(Shlomo., 1978)

On the basis of different researches on the low-income housing scheme, similar ones have been implemented in Asian cities like Bombay, Jakarta, Colombo, Manila, Dhaka and Taipei (Shlomo, 1978) and taking into account that it can be applied to diverse nations we use them as framework to develop the one that can be applied to the case study and we consider it as the first step in developing such method for understanding and evaluating the lowincome housing system and the housing condition in La Paz City.

Previous researches on the housing issue in La Paz City have been developed and used as tools for improving housing conditions; however some results are still general and specific problems can not be identified and solved yet, then the relevance of this research as result of the need of
* Ph. D. Candidate, Graduate School of Human-Environment Studies, Kyushu University

** Assoc. Prof., Faculty of Human-Environment Studies, Kyushu University, Dr. Eng.
九州大学大学院人間環境学府 博士課程 $\cdot$ M. Sc.

九州大学大学院人間環境学研究院 助教授 $\cdot$ 工博 
more detailed studies which can point out much better understanding of the low-income housing situation

\section{OBJECTIVES}

This study begins by giving some background about the housing conditions in Bolivia, followed by the case study of La Paz City where the urban growth process, social stratification and residential segregation prove to be closely interrelated, looking at the housing condition followed by a review on housing policies. Next, it finds out the different low-income housing types in order to construct the housing system scheme and then, it underlines on renta housing as an important option for the low-income people who can not afford to become owner-occupier due to their lack of resources. We do emphasis on rental housing, although it is not the highest percentage housing tenure since this becomes an important housing alternative, apart from ownership, for the economically disadvantaged. Finally the study ends by drawing conclusions.

This study is focusing on the following two main objectives:

1. To construct a hierarchical scheme, in which different low-income housing types can be identified in the case study of La Paz City, based on the housing strategies of the low-income people.

2. To point out the most important housing alternative and its characteristics, apart from ownership, since we consider that low-income people due to their disadvantaged economic situation can not usually become owner occupier, thus, they need to resort to other housing options.

By achieving these objectives, we aim to provide an enhanced understanding of the low-income housing types. It would be important to mention, that as a result of future researches the scheme can be added with some more housing types to be strengthened.

\section{RESEARCH METHOD}

As mentioned before, previous studies on the housing issue have been developed; however there is still the need to keep on studying more about the low-income housing conditions. Thus, although this research is not deep enough due to the scantiness of information, it intends to provide a portrait of the housing condition.

This study illustrates the research findings into the low-income housing system of La Paz City on the basis of an extensive study concerning the housing issue. Input from national data such as statistics information, housing diagnosis, housing policies, housing projects and previous researches as well as international literature to reinforce our knowledge on the basis that lessons can be learned from other cultures, have been used as information tool.

As framework, the first part examines summarily the housing situation at national level followed by the case study of La Paz City as one of the major urban areas in the country whose urban growth has been accelerated and influenced by different aspects. We elaborated an overview of the housing conditions as well as the role of government towards housing in order to get better understanding.

Next, it focuses on the low-income housing in which we could distinguish different housing situations and housing alternatives to which low-income people resort, from formal to informal market, from planned urban areas to

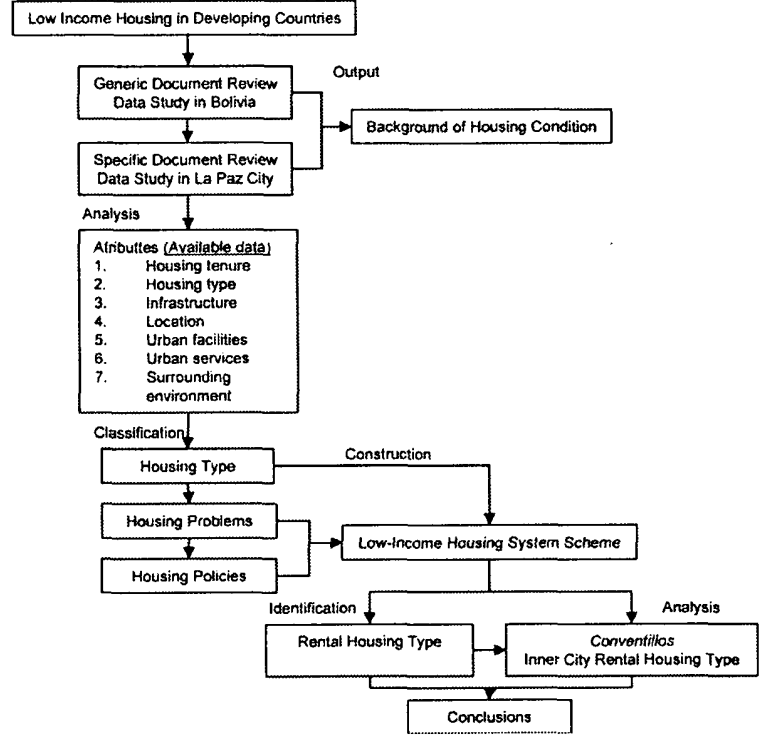

Fig. 2: Research Method and Flow

squatter settlements, and then by studying diverse components and attributes such as physical and social characteristics the classification of the different housing types was constructed shown through the low-income housing system scheme. Following, the identification of the most important low-income housing type and its characteristics; we aimed to focus on a different type than ownership since low-income people need to find another housing alternative due to their economical situation in which owner occupancy usually becomes unaffordable. Finally, the research ends by elaborating conclusions (See Fig. 2)

\section{BACKGROUND}

\subsection{Outline of Bolivia}

Bolivia, a landlocked country is situated in South America with 1,098,581 $\mathrm{km}^{2}$ and $8,274,325$ inhabitants (2001) with inter-census growth rate $2.7 \%$ (1992-2001). It is known as land of contrasts due to its many different ethnic cultures dispersed in its main three zones: highlands, valleys and tropic (See Fig. 3). According to statistics $62.4 \%$ of the population is settled in urban areas and $37.6 \%$ in the rural ones (INE, 2001). The central urban axis comprised by the three metropolitan areas, La Paz, Cochabamba and Santa Cruz concentrates the major activity, profits and population, in which $70.0 \%$ of the national housing stock is found (INE, 2001).

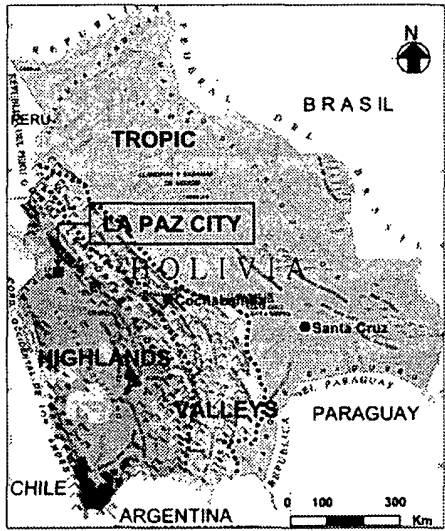

Fig.3: Map of Republic of Bolivia
Bolivia possesses an extended territory plentiful of natural resources with a great possibility to become a prosperous nation to offer wellbeing to its inhabitants, however the poverty levels are high in which about $59.0 \%$ lives in that condition. The migration trend is toward further urbanization, as the population in the main cities is 
growing at rate of $4.2 \%$ annually transforming a nation that used to be rural in great percentage into urbanized areas with low degree of human development (INE, 2001).

\subsection{Housing Overview}

In developing countries, like Bolivia, the housing problem is no only related to the lack of dwellings, but it also has structural development connotation. Since the housing problem roots are socio-economic, this affects directly to the social system stability.

A housing study carried out in 1996 estimated a quantitative deficit of approximately 250,000 houses, especially in the major urban areas and a qualitative deficit of 600,000 houses, which meant $43.0 \%$ of the total housing stock, being more relevant in rural area (Richmond, 1997). About $49.5 \%$ of Bolivian families inhabit in precarious housings, facing some kind of deficit related to construction materials, lack of basic services or another deficiency (INE, 2001). Based on the census of 2001, ownership is the first housing tenure followed by rental type, anticresis ${ }^{\prime \prime}$, cedida ${ }^{21}$ and others. Ownership is higher in rural areas in which nine out of ten families live in their own house whereas in urban areas only five out of ten. The housing problem is also accompanied by other factors; in urban area only $89.5 \%$ has electricity, $82.9 \%$ water supply and $82.3 \%$ either sewage or latrine. In rural area these figures show greater deficiency (INE, 2001).

Concerning to occupancy rates (number of persons per room), although the average number of persons per room was reduced from 2.4 in 1992 to 2.2 in 2001 , there are still people living in overcrowding conditions. For example, $64.1 \%$ have two or one persons per room, $25.1 \%$ three or four, $7.6 \%$ five or six, and $3.1 \%$ seven or more. In urban as well as in rural area, most of the families have two or less persons per room, however about $3.1 \%$ of the housings show high degree of overcrowding, in which more than seven persons live in one room (INE, 2001).

\subsection{Outline of La Paz City}

La Paz is the highest capital city in the world, 3,600 meters above sea level with $1,496,387$ inhabitants (2001). In appearance, it seems to be a big oval bowl in which the modern downtown area is comprised by a line of skyscrapers given additional character by the majestic mountain Illimani, which keeps snow-covered all year long (See Fig. 4 and 5).

The city is geographically divided into three levels: El Alto", named "land on heaven" located 600 meters higher than La Cuenca ${ }^{4}$, offers the most housing opportunities for the low-income people in which the massive population with indigenous origins has strong influence in the urban

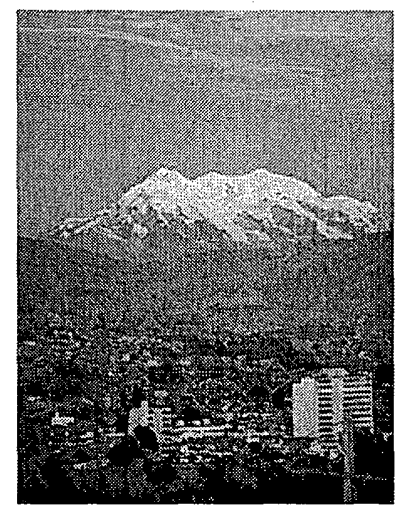

Fig. 4 View of La Paz City structure showing a notable predominant rural mentality, in La Cuenca or central area the old colonial mansions have either become commercial buildings or residence - conventillos- for an important segment of the low- income people as well as middle class, and in El Bajo ${ }^{5)}$, which is the lowest point, the upper class settles in the bestequipped neighborhoods. Then, it is

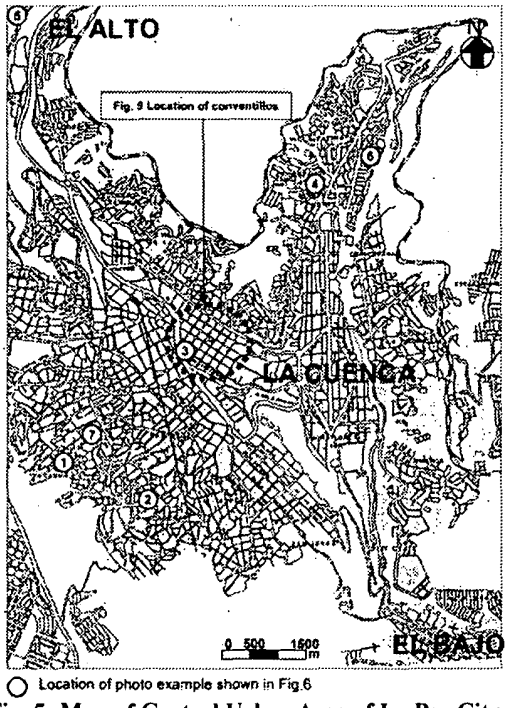

Fig. 5: Map of Central Urban Area of La Paz City understood that the geography in the case of La Paz City plays an important role on the housing conditions. (Kabayama, 1981)

The low -income people live at higher altitude, where infrastructure in many neighborhoods is still scarce and vegetation almost does not exist due to the cold and dry weather. The urban growth of this settlement, which not long ago was designated as industrial zone, is mainly as a result of spontaneous settlements.

\section{OVERVIEW OF LOW-INCOME HOUSING CONDITION}

The informal housing sector has developed most of the houses in La Paz City, it is not only because the formal mechanisms are insufficient to provide public housing, but also because the informal sector is more labor-intensive than the formal and invests less capital than does formal-sector construction. However, informal-sector construction is predisposed to face health and safety risks in which the poorer families are more likely to confront housing problems where inadequate housing also impacts the physical and psychological development of its inhabitants.

In order to construct the low-income housing system scheme it is necessary to understand the housing condition of the low-income people, however there is neither precise statistics nor specific information. Thus, the following housing problems mentioned below could work out as the most striking features of poor housing. Nevertheless, it would be important to point out that for future research, the construction of the scheme will allow to identify those specific housing problems that are needed to know in order to improve the housing condition.

\subsection{Overcrowding}

Overcrowding still keeps on being an acute problem since there is not relationship between the available number of bedrooms and the number of family members. Regulations concerning housing point out that there must be 1.5 person per bedroom (POU, 2002), however in La Paz City statistics show a rate of 2.36 persons per bedroom generating not only incompatibility of uses but also as a result of the limited space, psychological factors develop affecting the occupiers' behavior. $61.2 \%$ of the total families has two or less persons per bedroom, $18.5 \%$ has two or three and $20.3 \%$ has more than three (INE, 2001). The problem is getting worse because housing cannot 
keep up with the increasing urban population.

\subsection{Infrastructure}

Although there has been improvement on the endowment of basic services, this still is a striking feature of poor housing. Only $52.2 \%$ has domiciliary connection to drinking water, the remaining gets it from cistern car, public tap or water well. About $43.1 \%$ has sewage, and $56.9 \%$ lacks completely of this service (36.8\% has septic well and $20.1 \%$ resorts to other means). Even though $72.6 \%$ has electricity, most of the peripheral neighborhoods do not have street lighting, which derives on dangerous and unsafe places to walk through. (INE, 2001).

\subsection{Environment degradation}

The quality of urban environment and the role of the housing sector are tightly linked; the urban as well as the residential environment enclose important factors for the quality of housing. Everyday, 80 metric tons of waste are illegally thrown either into rivers or ravines, polluting not only water and air but also vegetables and fruits since the river water is used for irrigation. To this environment degradation, animal blood originated by slaughterhouses placed in the rivers can be added. (POU, 2002)

\subsection{Quatitative and qualitative deficit}

Statistics have never been precise to show the exact quantitative and qualitative housing deficit because of the lack of detailed, reliable and periodical data. In 2001, it was estimated quantitative deficit of $0.85 \%$ and qualitative of $37.64 \%$ (INE, 2001). Two important factors that make shortage not increase abruptly are the fact that many low-income people resort to self-built based on appropriate technology using traditional materials, and the existence of kinship, in which the ones who can not own a house can live with their relatives.

\section{GOVERNMENT POLICIES TOWARDS HOUSING}

For the last seven decades the Bolivian government has elaborated different laws, decrees and housing policies attempting various measures in order to address housing needs. However, there is not specific legislation that offers improvement of the living standards of low-income people or resolves their housing problems, and then it becomes difficult to evaluate the specific results (MVSB, 2002).

\subsection{0s-1990 Period}

In 1928 , the first attempt to create a housing institution was made without success due to the great depression that originated the bankruptcy of the world bank system, however the long-term housing financing system started through mortgage bonds. Few years later, the economic situation got worse because of the Chaco War and it continued until the 1952 revolution, from this year till 1964 the public housing supply was minimun: 1507 unit housings oriented to middle-upper class were constructed.

In 1957, the different laws to create housing councils were promulgated, reinforcing the compulsory saving ( $2 \%$ out of montly salary), insuficient to provide housing without subsidy. However the government constructed housing for journalists and rail way workers, but not for low-income people. Between 1957 and 1986, 20.000 housings were built out of the 60.000 that were requiered.

In 1965 , with the beginning of militar regimes, it started a massive construction of multi-family housing oriented to middle class. This was financed by the United States.

In 1987, after the economic hyperinflation, the National Housing Fund was created to replace the housing council. Since the organization system was similar to the previous one, where loans were given in US dollar financed by long-term credits with short-term obtained resources from the public contributor. This originated collapse in the financial system, thus theNational Housing Fund had to be closed in 1997. About 26.600 different housings and urban improvement projects were elaborated by the end of its closing. Therefore, in 1998 a new period of new housing policies and reforms started.

\subsection{From 1998 to the present}

Since early 1998 the Ministry of Housing and Basic Services has been implementing the National Housing Policy with three main pillars: the National Program of Housing Subsidies, the Program for the Risk Prevention and Mitigation, Emergency Management and Extreme Poverty and the Development of the Secondary Credit Market (Poverty Reduction Strategy Paper, 2001). Even though some of the programs are been executed, the other ones are still under feasibility and regulation revision, then it would take some time to evaluate the appropriateness.

Most of the housing policies have been not addressed towards the lowincome people who are the most affected by the housing problem. There are not specific statistics about the housing projects for the low-income people, however by looking at national level, where only $23.0 \%$ of the total housing demand has been supplied; we could understand that the low-income people are being lagging behind resolving by themselves their housing need.

\section{LOW-INCOME HOUSING SYSTEM SCHEME \\ 7.1 La Paz' housing classification review}

In order to construct the low-income housing system scheme in La Paz City, we used as departure point and comparing instrument the former model "tree structure" implemented in some Asian cities during the 1970 s (Shlomo,1978).

On the basis of all the available data, we idenified that housing was classified into three main groups, which worked out as reference to obtain more detailed housing types classification (INE, 2004)

First, it was found out the existence of four main housing categories based each of them on construction materials quality framed into three variables floor, structure and roof: I) good quality construction materials, II) average, III) where one or two components have poor quality and IV) precarious.

Second, it classified housing on the basis of tenure into seven main categories: 1)Ownership, 2)Rental, 3)Anticresis,4)Mixt Anticresis-Rent-Free payment, 5)Work Place, 6)Cedida and 7)others.

And third, based on housing type making reference to a)House, b)Apartment, c)Single Room, d)Mobile, e)Improvised and f)Non Destined Housing Use.

These three housing categories were useful tools not only to understand the general classification but also to identified more specific housing types 7.2 Housing categories as basis of classification (See Fig.6 left)

A. Squatter housing sub-system: Defined as units of self-constructed 


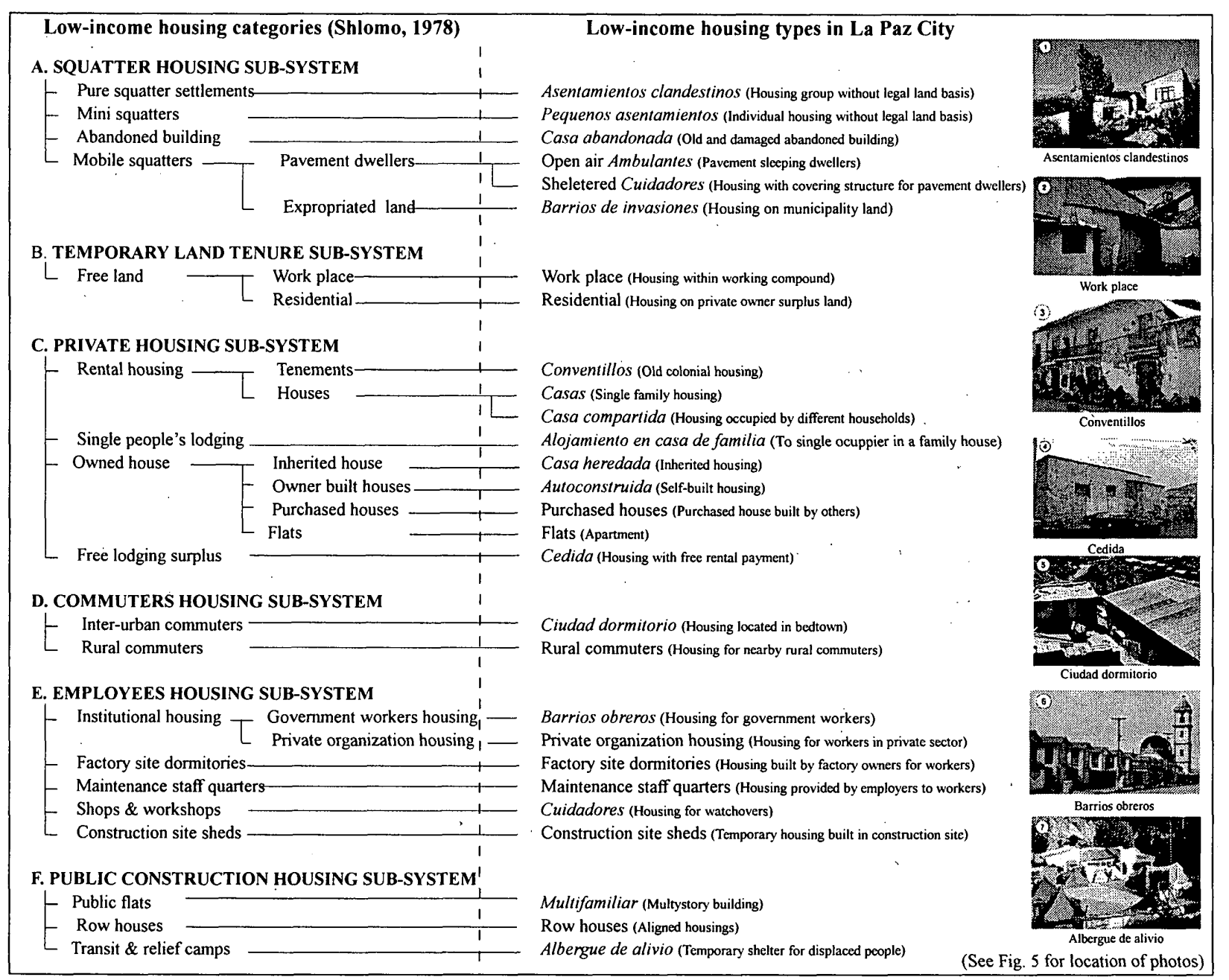

Fig,6: Low-income Housing System Scheme in La Paz City

housing built on terrain seized and occupied illegally; either private or public land is inhabited by the very poor and developed without legal claims to the land and/or permission from the concerned authorities to build

B. Temporary land tenure housing sub-system: Land is acquired temporarily either by paying rent or free-rent, in which the landowner and the new occupant establish contract rules based on common agreement.

C. Private housing sub-system: There is private ownership in which dwellers own land and house without any governmental or institutional commitment.

D. Commuters housing sub-system: People who regularly travel from one place to another on a daily basis for the purpose of employment. They are not always low-income people, however in order to cover their higher travel costs they resort to low housing expenses which differenciates from the Private Housing Sub-system that is oriented specifically to low-income people, then the commuters's housing have sub-standard conditions.

E. Employees housing sub-system: Employers of either public or private institutions provide housing for their employees.

F. Public construction housing sub-system: Government is directly involved in the supply of housing.

\subsection{Matching process}

After the data review, taking into account, on the one hand, the three components: category, housing tenure and housing type (See Fig. 7), and on the other hand, the structure of the former scheme (See Fig. 1), we proceeded to match each other in order to find out the similarities and disparities of the housing types. Making use of the matching process and taking up different and specific existing housing types we identified: six different types in $A$, two in $B$, nine in $C$, two in $D$, six and $E$ and three in $F$. As a result, twenty eight different housing types could be found out where for some of them their original Spanish name is used. To make this classification on the one hand, we used all the available information about

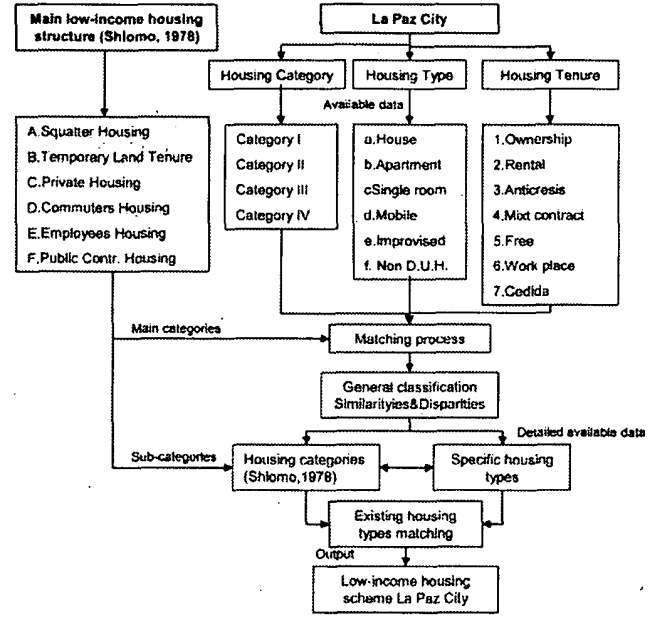

Fig.7: Method of housing types classification 
the existing housing types and did survey for each housing type to ponit out its characteristics. In Fig. 7 the diagram shows the method of elaborating the low-income housing classification:

\section{RENTAL HOUSING TYPE}

\subsection{Rental housing as an important alternative}

The low-income housing sub-system scheme enabled to know different housing types, from which we were able to find out that rental housing type, enclosed in the private housing sub-system, has come into being one of the most important alternatives for the low-income people. As mentioned before, we wanted to focus on a different type than ownership considering the disadvantaged economic situation of the low-income people who can not afford to become owner-occupier and need to search for a different alternative.

In La Paz, low and middle-income households prefer to own their housing, to live close to the center or to live in independent houses prior to other housing types. However, the preferences for ownership and location in $\mathrm{La}$ Cuenca are contradictory to the reality due to the limited available vacant housings, resulting in prices and rents that cannot be easily affordable for the low and most of the middle-income people. Ownership can still be achieved by building a house in El Alto; however this does not only imply a long distance from the city center but also low services level (Beijaard, 1995). Then, rental housing has become an important option to be accessible to the low-income people.

Based on statistics, in $\mathrm{La} \mathrm{Paz} 44.3 \%$ of the population are not homeowners, $22.6 \%$ live in rented accommodation, $7.9 \%$ under anticresis contracts, $12.1 \%$ in cedida and the remaining $1.6 \%$ in others (See Fig. 8). Although most of the information is based on census statistics and these numbers are not wholly reliable, they work as indicative of trends (INE, 2001). Rented accommodation is not only found in the planned neighborhoods but also in the spontaneous settlements where squatters rent out a room to individuals or families in order to supply their income. In many areas there are more cheap rooms available for renting within illegal settlements than within the traditional tenement.

The assertion that rental housing type is being an important shelter need alternative has been also considered by the World Bank as a new priority within the market housing for the low-income people, because, on the one hand, house owners can satisfy easily and faster their financial obligations if they rent a part of their houses, and on the other hand, supporting rental housing type would offer new housing opportunities for the economically disadvantaged (Beijaard, 1995). In La Paz, since most of the housing policies have been prompted first by the housing councils and later by the banking system or private funds, where in the former, most of institutions have been closed due to deficient administration and lack of specific housing measures mainly addressed to the most disadvantaged, and in the latter where credits are not accessible for the majority of low income people, specially for those

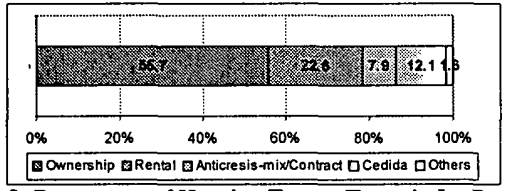

Fig.8: Percentage of Housing Tenure Types in La Paz City Source: Instituto Nacional de Estadistica, 2001 who have no fixed employment, work in the informal sector and the ones who can not fulfil the requirements of financial institutions. Therefore, renting plays an important role becoming an accessible housing tenure for the lowincome people. However, it does not exist any policy concerning living standards improvement of low income tenants (MVSB, 2002).

\subsection{Inner city rental housing}

Rental housing can be found in the different settlements of La Paz City, from planned neighborhoods to spontaneous settlements, from inner city to peripheral areas, and from formal to informal market, in which the characteristics vary from one place to another. We found out that renting in inner city, focused on conventillos type, is also a good alternative for lowincome people, however the conditions in which they live are great dilapidated and these conditions are becoming factors for the declining of inner city.

Conventillos are also an oldest type of housing for low-income people not only in La Paz City but in many modern Latin American cities. We' aim to illustrate the development of this inner city rental housing type, not only because it has not often been a study topic since more attention is paid to the urban periphery but also because it is known that housing conditions are worse than they were assumed. Based on the residential people's opinion report (POU, 2002), the physical environment of inner city is mainly affected by waste disposal on public space, change of sidewalks into crowding commercial use due to street vendors, traffic congestion, and in addition deterioring of conventillos which were constructed since 1548 deriving in collapsing or abandoned buildings.

\subsection{Conventillos}

An old colonial mansion with a central patio surrounded by rooms connected through a gallery where the residents rent their accommodation is known as "conventillo" (See Fig.9). These settlements are directly connected with the historic center and some located near to the Presidential Palace, characterized by physical deterioration and inhabited by several households in which the most important reason for the residents is to remain in the centre close to job opportunities. (Kabayama, 1981)

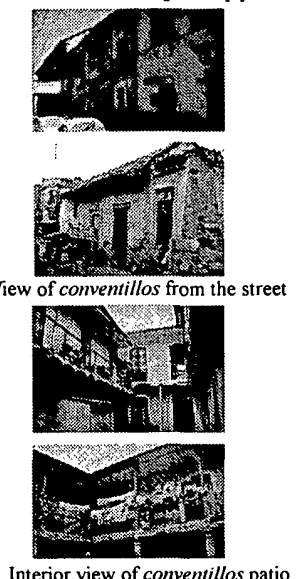
Fig.9: Example of Conventillos Located in Inner City of $\mathrm{La} \mathrm{Paz}$

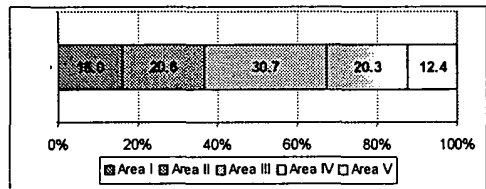

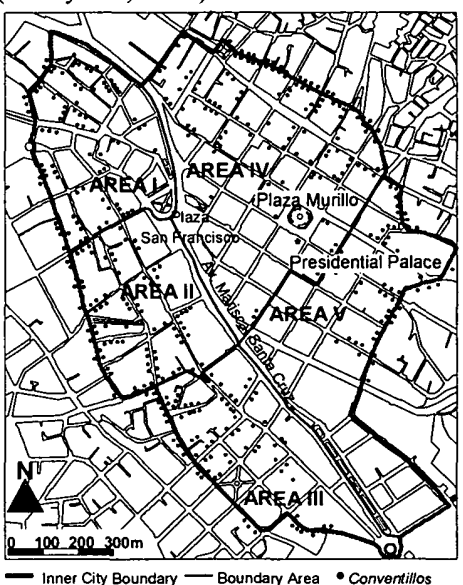

Fig. 10: Location A reas of Conventillos in Inner City of $\mathrm{La} \mathrm{Paz}$

(Total inner city lots: 1800 conventillos: 400 approximately) Source: Los conventillos, vivienda en alquiler en el centro de $\mathrm{La} \mathrm{Paz}$ Location of conventillos based on the original field survey.
Fig. 11: Distribution by Area of Conventillos in Inner City of $\mathrm{La} \mathrm{Paz}$ Source: Los conventillos, vivienda en alquiler en el centro de $\mathrm{La} \mathrm{Paz}$ 
In an other Latin American countries conventillos are known as "casas subdivididas" (sub-divided houses) in Lima, "casas de comodo" (lodging house) in Rio de Janeiro; or "vecindades" (vicinity) in Mexico (Beijaard, 1995). For example in the case of Mexico City there is high concentration of overcrowded rented tenements where the central patio has shrunk becoming a narrow passage to provide access, sunlight, ventilation and semipublic space in which $9.9 \%$ of each family housing has just one bedroom and in Lima, they have been called the invisible sector of the housing market estimating that about 100,000 people live in these slums, although innercity rental housing is of lesser importance in quantitative terms than the peripheral housing, this constitutes a significant housing alternative for the low income people (UNHS, 2003)

In La Paz' inner city their actual number is estimated at 400 , with an average occupancy of eight households per conventillo housing an average of 3.2 persons, it means that there are about 10,000 persons living in the central urban quarter. This area, considered as cultural heritage because this was the first place to develop since the Spaniards arrival, was delimited by the municipality into five different ones on the basis of origin (built in or post-colonial eras until about the 1940s), architectural style and function.

In Fig. 10 and 11, we can observe the distribution of conventillos: area III shows the highest percentage $(30.7 \%)$ because this area still predominates as housing, and conventillos remain where the largest ones can be found (Garage Romero), whereas in areas II (20.6\%) and IV (20.3\%) the ratio is more or less similar since in the former due to its touristy location (San Francisco convent, Witch Street, Sagarnaga Street ) many conventillos have been transformed into small commercial shops, in the latter the percentage is just a little bit less because most of this area corresponds to the administrative buildings (Presidential Palace, Congress, Central Bank), some conventillos are kept most for cultural purposes than for housing .

Area V $(12.3 \%)$ is directly connected to the main avenue (Mariscal Santa Cruz) which structures La Paz City, in which a line of skyscrapers mixed with few conventillos can be distinguished. In this area there are less conventillos because they are being replaced by the new apartment buildings that are increasing rapidly. Although area I (16.0\%) was one of the most important places, since it was the first central city during the colony, conventillos are been replaced by new buildings, mostly commercial ones since part of this area belongs to the big open market that exists in the city.

Most conventillos, whose number of rooms varies from eight to forty, maximizing the use of the existing space, built in an average area of $600 \mathrm{~m}^{2}$, face deteriorated quality conditions, high built up density, lacking maintenance in which water and sewage networks are in poor condition, facing ruinous state in imminent danger of collapse or some are inhabitable and need to be demolished. The conventillos are constructed from adobe ${ }^{6}$ which make them to be more susceptible to deterioration, especially during rainy season where humidity affects the structure. Since the inhabitants have little economic resources they do not invest on reparation or maintenance, only in rare cases landlords constructs additional facilities.

The dilapidated characteristics of conventillos remains the same as they use to did a few decades ago. The government still keeps passive and tenants have no other choice than remain in substandard conditions.

\section{CONCLUSION}

This research enabled us to identify six main low-income housing subsystems which derive in twenty eight different housing types for low-income people. The significance of this low-income housing system scheme in La Paz City remains important in order to obtain better understanding about the housing types to be accessible to the urban poor. This points out that low-income people resort to a variety of options in order to obtain housing, but this does not in any way imply that they succeed in satisfying their housing needs where it is seen that many people live in substandard housing.

Ownership is the preferred form of tenure, however, due to the rapidly increase of land prices and the disadvantaged economic situation of the lowincome people, rental housing is considered as an important alternative. The great number of renters in La Paz City shows the importance of rental market absorption capacity. Although this is an important house tenure, there is still the lack of specific legislation that supports specially tenants. Different decress and laws have improved somewhat the renting system during $1930 \mathrm{~s}$ to the begining of $1970 \mathrm{~s}$ where these regulationes were replaced by the Civil Code which contains references to contracts, evictions, anticresis and letting , however there has not been an specific legal instrument to protect either tenants or elements to deal about rent payment, living conditions and others (Richmond, 1997).

The low-income housing system scheme aims to provide specific information in order to obtain better understanding of the different housing types for low-income people, it could be considered as a starting point for future researches for planners and decision makers in order to improve the housing conditions for the low-income people.

In addition, with the result of future research, the scheme can be improved, multiplied and strengthened, thus it could work out as basis for new lowincome housing system schemes in another cities of Bolivia, where the housing conditions also need to be improved.

NOTES

1) Contract by which the occupier gives an amount of money to use a property during a set period of time; at the end of the contract the money will be given back.

2) Tenure situation in which a dwelling is temporarily lent without charging any rent.

3) El Alto means The Highest, named due to its geographic location 4200 meters above sea level 4) La Cuenca Named like this because its basin shape, located at 3600 meters above sea level 5) El Bajo Means The Lowest, named due to its geographic situation, 3200 meters above sea level 6) Mud mixed with straw dried in the sun and used as a constructing material

BEIJAARD, F. (1988) Los conventillos, vivienda en alquiler en el centro de La Paz, Editor CEDLA,

La Paz.
BEIJAARD, F. (1995) Rental and rent-free housing as coping mechanisms in La Paz, Bolivia, in ESTAMANTE $G$ et al (1996) Quito: Politicas de vivienda Ediores Municipio Metropolite

Quito 1 (1997) La vivienda en Bolivia diagnostico y politicas, Editor UDASPO, La Paz GILBERT, A. (1994) The Latin American City, Latin American Bureau, London, 18

GISBERT, T. (1991) Historia de la vivienda y los conjuntos urbanos en Bolivia Academia Nacional de Ciencias de Bolivia, PUB. No. 454 Edición del Instituto Panamericano de Geografia e Historia. México, D. F.

HARDOY, J.E. et. al. (1989) Squatter citizen, life in the urban third world, Earthscan Publication Ltd, London, 170-17

INE (2001) Instituto Nacional de Estadistica, Censo de Población y Vivienda

KABAYAMA, K et al, (1981) Andes Kouchi Toshi La Paz no Shouzou, Tosui Syobo (in Japanese) Ministerio de Desarrollo Humano (1997) Lineamientos para una politica nacional de As (2002) Ministerio de 1 ivienda y Asentamientos Humanos, $42-45$

Housing in third world countries, perspective on policy and practice Macmillan International College Editions, Australia

POU (2002) Plan de Ordenamiento Urbano, Fundacion Cuerpo de Cristo La Paz

Republic of Bolivia (2001) Poverty reduction strategy paper, 102

RICHMOND, P. (1997) From tenants to owners: experiences with a revolving fund for social housing Environment and Urbanization, 9 (2), 120

ROJAS, E. et al (1995) Reaching the poor: lessons from the Chilean housing experience, in Environmental and Urbanization, Urban Poverty II: from understanding to action, 7 (2), 31

SHLOMO, A et al, (1978)The low-income housing delivery system in Asia, International Conference on Low-income houisng: technology and policy, Asian Institute of Technology, Bankok, 3, 1177 1218

TURNER, J. (1976) Housing by people, towards autonomy in building environments, Marison Boyards, London

UNHS (2003) United Nations Human Settlements, Undertanding slums: Case studies for the global report of human settlements 2003.http://www.ucl.ac.uk/dpu/publications/cd_slums.htm

AN LINDERT, P (1991) Household shelter strategies in comparative perspective: Evience fromlow-

income groups in Bamako and $\mathrm{La} \mathrm{Paz}$, World Development, $19(8), 1013$ 


\section{和文要約}

本論文は, 発展途上国の都市における低所得者層の住宅実態の全 体像を把握するため, 住宅の類型化とその類型の階層的な体系化に 関する研究として,多様な低所得者住宅が分布している南米ボリビ アの首都ラパス市を対象とし, 既往研究の低所得者住宅の体系化の 方法を参照しながら, 文献調查や現地調查を行い,同市の住宅類型 の定義を明確にし,これまで整理されることのなかった住宅類型の 体系化を行った成果をまとめたものである.本論文の各章の概要は 以下の通りである.

第 1,2 章においては, 本研究の背景と目的について言及してい る、特に, 本研究に取り組む背景として,これまでボリビアでは経 済発展の一方で, 国民全体の約60\%に当たる低所得者層の住宅の多 くは, 基礎的な衛生設備もなく小規模, 過密で外部環境からの保護 も十分とは言えない深刻な問題を多数抱えている実態があり，低所 得者層への基本的な住宅供給と経済的援助において十分な効果を上 げられなかった点を指摘している.ラパス市の低所得者住宅の実態 や問題解決に関する詳細な研究は十分行われておらず,本研究で対 象とする低所得者住宅の類型と体系化は, 多様な住宅問題や住環境 改善に関する包括的な対応策を検討するための基礎的研究として必 要とされている。

一方, 1970年代以降に主としてアジア地域における低所得者住宅 をテーマとした国際会議や既往研究において, 低所得者住宅の体系 化がッリー構造の階層的分類として整理されてきた. 同様な体系化 は, 低所得者住宅の全体像と住宅問題を理解する方法として,アジ アの諸都市に取り入れられてきた.本研究は,こうした発展途上国 での体系化方法を参考にしながら, ラパス市の状況を踏まえて, 独 自の調査に基つき低所得者住宅の体系化を行うものである。

即ち, 本研究では, 次の2点を主要目的として研究を行っている.

(1)ラパス市の状況において, 低所得者住宅の全体像を把握するため

の住宅類型を整理し,全体像を体系的に把握すること.その住宅 体系は,他都市で行われた既往研究の階層的体系を参照しつつ, ラパス市に関する文献調查, 現地調査により現在の低所得者住宅 の各類型を整理することから導き出すこととする．

(2)構築した住宅類型の体系からラパス市の低所得者にとって最も重 要な住宅タイプの一つとして貸貸住宅を抽出し,その実態㧍よび 居住環境整備上の課題を明らかとすること.特に, 高密度な都心 部の市街地におう型的な実例を挙げて実際の住宅事情を分析 する.

また,これらの目的に基づく調查・分析を通じて, ラパス市の住 宅問題に対する理解を深めることも副次的な目的と考えている.

第3章では, 本研究の方法について説明している.まず, ボリビ アおよびラパス市の住宅に関する文献調査と統計データの分析から 住宅問題の社会的, 地理的背景を整理し(第4章), ボリビアにおけ る低所所得者住宅に対する政策の歴史的変遷を整理している（第 5 章).それらの背景を踏まえた上で, 文献調查および筆者の実務経 験や現地調査からラパス市の既往の低所得者住宅の類型ごとの属性 を基に, 第 7 章に示寸住宅体系を作成した. 更に, この住宅体系の 中でも多数を占める賃貸住宅の類型に焦点を絞り, 現地調査や文献 調査に基づき,高密度市街地に打ける賃貸住宅の実態と課題を明ら かにしていった.
第 4,5 章では, 南アメリカの中心に位置するボリビアおよび高地 に位置するラパス市の概要と低所得者住宅を取り巻く社会的, 地理 的背景等と住宅問題全般を整理している.ボリビアの貧困の程度の 高さや住宅の整備状況について統計的な数值で把握を試みた.統計 資料を整理することによって,都市地区および郊外地区それぞれに おける高い人口増加の実態と多数の住宅困窮世帯の存在を示した. また，海抜 $3,600 \mathrm{~m}$ に位置し，人口約 145 万人のラパス市は，ボー ル状の器に似た地形で都心部（低地）と郊外部（高地）とでは $600 \mathrm{~m}$ もの高低差があり，郊外部は近年の低所得者の受け血となってい る.特に同市が直面している主要な住宅問題を文献調査および筆者 の実務経験と現地調査に基づき整理すると, (1)過密化, (2)住宅イン フラ設備の不備, (3)環境の悪化, (4)住宅の量的不足が挙げられる.

続いて第6章ではボリビアの住宅政策の変遷を整理している.過 去70年間,ボリビア政府はそれぞれの時代ごとに異なる低所得者住 宅の政策を実施し，最近まで政策転換と再編成を繰り返してきた が,住宅問題を解決する程の経済力がなく, 政策運営上の問題に直 面して, 低所得者住宅の改善に有効な手段を持たないために, 住宅 供給や環境改善に効果を上げるに至らなかった点を指摘している.

第7章では, 文献資料および現地調查からラパス市内に立地する 低所得者住宅の様々なタイプを洗い出し,その属性と立地条件等を 分析し，整理を行い，A. 不法占拠住宅，B. 仮設住宅，C. 私有住宅， D. 通勤者住宅, E. 従業者住宅, F. 公営住宅の6つのカテゴリー(サ ブシステム)の下に, 低所得住宅の分類, 整理を行った。その結果, 表記の階層的な住宅体系を構築することができた.この住宅体系 は, 現存するラパス市の多様な低所得者住宅の全体像を網羅してお り, 各住宅類型別に住宅問題を整理し, 理解する上での情報整理の プラットフォームとして活用することも想定している.

次に, 第8章では, 前章で構築した住宅体系から低所得者層に重 要なカテゴリーである貸貸住宅を取り上げ, 中心市街地における賃 貸住宅の実態を調查し，その課題を明らかとしている．中でも， Conventillos と呼ばれる貨貸住宅の類型は, 植民地時代に建設され た市の中心地区に多く立地するものである.Conventillosは, 既存 の部屋を活用して貸貸されているが, 高密度で老朽化した上に維持 管理状態も悪く, 改善を要する住宅が多数含まれている点を現地調 査および統計資料等に基づき指摘した。

最後に結論として, 本研究で構築した住宅体系の特徵とその有効 性を以下の3点にまとめている. 発展途上国の住宅問題の実際の深 刻さは計り知れない上,求められる解決策を,どこから始めて見つ ければいいのかも未知である。それゆえに, まず 1 点目として階層 的な住宅類型の体系は, 低所得者への住宅供給システムの図式化と して見ることもでき, 低所得者の住宅確保の実態を把握し, 住宅問 題の理解に役立たせることも考えられる。

2 点目は,この体系化と住宅供給システムの図式化では, 低所得 者住宅の多くを占める賃貸住宅を体系的に整理し, 様々な呼称の賃 貸住宅を体系の中で位置づけたことである.これにより体系的に貨 貸住宅に関わる各問題の整理を行うことができる.

3点目は,こうした低所得者住宅の体系の構築方法の応用と一般 化に関してである.階層的な体系化の方法は, 本研究がラパス市に 対して行ったように,同じ目的を持った発展途上国の他都市にも適 用でき, 他都市でも住宅問題の整理と把握に役立つと考えられる。 